\title{
A multidisciplinary approach to restore crown-root fractured maxillary central incisors: orthodontic extrusion and surgical extrusion
}

\author{
Eun-Young Kwon', So-Yeun Kim¹, Kyoung-Hwa Jung', Youn-Kyung Choi', Hyun-Joo Kim²,3, Ji-Young Joo ${ }^{2,3 *}$ \\ 'Dental Clinic Center, Pusan National University Hospital, Yangsan, Republic of Korea \\ ${ }^{2}$ Department of Periodontology, Dental and Life Science Institute, School of Dentistry, Pusan National University, Yangsan, \\ Republic of Korea \\ ${ }^{3}$ Department of Periodontology and Dental Research Institute, Pusan National University Dental Hospital, Yangsan, Republic \\ of Korea
}

To restore a tooth with a fracture line extending below the marginal bone level, a surgical crown lengthening procedure accompanied by ostectomy could be considered to expose the fracture line and reestablish the biologic width. However, this procedure could lead to esthetic failure, especially in the anterior teeth. Therefore, orthodontic extrusion, which elevates the fracture line from within the alveolar socket without sacrificing the supporting bone and gingiva, is recommended. This technique allows for the proper placement of the crown on a sound tooth structure, with the reestablishment of the biologic width. Alternatively, surgical extrusion is an one-step procedure that is simpler and less time-consuming than orthodontic extrusion; placing and adjusting the orthodontic appliance does not require multiple visits. This study presents successful restoration in 2 cases with a crown-tooth root fracture of the maxillary central incisor treated using a multidisciplinary approach through orthodontic extrusion or surgical extrusion followed by successful restoration. (J Dent Rehabil Appl Sci 2020;36(4):262-71)

Key words: crown lengthening; orthodontic extrusion; surgical extrusion; tooth fractures

\section{서론}

파절된 치아는 파절 위치에 따라 다른 치료법이 적용되 는데 치관-치근 파절 또는 치경부에서 치근 파절은 치관 부 수복을 어렵게 만든다. 변연골 하방으로까지 파절선 이 연장될 때 수복시 가장 주요한 문제는 적절한 치관부 ferrule의 부재와 생물학적 폭경의 침범이다. Ferrule은 주조 전장관을 위한 치아 삭제가 이루어진 변연부에서 치관측으로 연장된 상아질의 평행한 벽을 둘러싸는 주조 전장관의 360도 collar로 정의된다. ${ }^{1}$ 예지성 있는 수복물 제작을 위해서는 수복물 변연이 최소한 $1.5-2 \mathrm{~mm}$ 이상

*Correspondence to: Ji-Young Joo

Associate Professor, Department of Periodontology, Dental and Life Science Institute, School of Dentistry, Pusan National University, 20 Geumo-ro, Mulgeum-eup, Yangsan, 50612, Republic of Korea

Tel: +82-55-360-5103, Fax: +82-55-360-5194, E-mail: joojy@pusan.ac.kr. Received: August 14, 2020/Last Revision: September 7, 2020/Accepted:

September 9, 2020
의 건전한 치질을 감싸고 있어야 한다. ${ }^{2}$ 생물학적 폭경을 유지하기 위해서는 수복물 변연에서 치조정까지 최소 3 $\mathrm{mm}$ 가 필요한데 이것은 적절한 수복과 치은 조직의 치유 를 위한 필수 요건이다. ${ }^{3}$

치관-치근 파절이 발생하여 수복을 위한 충분한 ferrule의 길이를 얻을 수 없거나 생물학적 폭경의 확보 가 어려운 경우 흔히 발치 후 임플란트 치료 또는 브릿지 치료 등이 진행된다. 그러나 발치 하지 않고 해당치아를 유지하고자 할 경우 치조골 삭제를 동반한 치관 연장술 을 시행한 이후 수복을 고려해 볼 수 있다. 이 방법은 파 절 부위의 노출 및 수복을 위한 새로운 생물학적 폭경의

Copyright@ 2020 The Korean Academy of Stomatognathic Function and Occlusion. (c) It is identical to Creative Commons Non-Commercial License. 
재확립을 가능하게 하나, 술식으로 인해 심미성이 훼손 되거나 치주 조직의 지지가 위협을 받을 때는 적용하기 곤란할 것이다. 특히 심미성이 중요한 전치부에서 치간유 두와 치은 변연 위치의 보존은 만족스러운 치료 결과를 얻는데 필수 요건이기 때문이다.

만일 파절선이 유리 치은 변연보다 하방에 위치하면서 치근의 길이가 충분하다면, 교정적 정출 술로 파절 부위 를 노출 시키고 수복을 위한 생물학적 폭경의 재확립을 가능케 할 수 있다. ${ }^{4}$ 또한 교정적 정출술이 완료되고 난 후 인접 치주 조직과 조화로운 형태를 이루는 수복을 위 해 상방으로 증식한 치은이나 침착된 치조골에 대한 치 은 절제 및 치조골 삭제를 동반한 치관 연장술을 시행하 더라도 심미성이 훼손되지 않는다. 반면, 교정적 정출술 을 시행하지 않고 치관 연장술만 시행하는 경우 치은 절 제 및 치조골 삭제로 인한 비심미적 치료 결과를 피할 수 없다. 따라서 전치부에서 치아 파절이 발생했을 경우 교 정적 정출술을 적극적으로 고려해 볼 수 있다. 또 다른 대 안으로 외과적 정출술을 고려해 볼 수 있는데, 이 술식은 파절된 치아를 발치하여 새로운 위치에 고정시키는 방법 으로 파절 부위를 치은 연상 위치로 옮기면서 건전한 치 질을 노출시켜 생물학적 폭경의 재확립을 유도하는 것이 다. ${ }^{5}$ 한번의 술식만으로 정출이 완료되므로 교정적 정출 보다 방법이 훨씬 시간이 적게 걸리며, 복잡한 교정 장치 를 쓰지 않아도 되는 장점이 있다.

본 연구에서는 상악 중절치에서 치관-치근 파절이 발 생한 경우에 발치 하지 않고 교정적 정출술 또는 외과적 정출술을 통하여 수복한 증례를 보고하고자 한다.

\section{증례보고}

\section{증례 1}

14세 남자 환자로 4년전 외상으로 상악 좌측 중절치 부위에서 치관-치근 파절로 인해 치수가 노출되었으며 당시 치근첨이 완성되지 않은 미성숙 영구치였기 때문에 통상적인 근관 치료를 진행하지 못하고 근첨 형성술을 시행한 후 광중합 레진으로 수복한 상태였다. 이후 다시 외상으로 기존의 광중합 복합 레진 수복 부위 탈락 및 치 관-치근 파절로 본원 치과에 내원하였다(Fig. 1). 파절 부 위가 치은 연하로 연장되어 있어서 통상적인 수복에 어려 움이 있어서 파절 부위를 치은 연상으로 노출시키고 수 복을 위한 생물학적 폭경을 재확립하기 위하여 교정적 정출술을 시행하기로 하였다.

교정적 정출술을 시행하기 전에 러버댐을 이용한 격 리 및 방습하 근관 치료를 먼저 완료하기로 하였다. 기존 의 근관내 충전되어 있던 Vitapex로 추정되는 물질을 깨 끗이 제거 후 mineral trioxide aggregate (ProRoot MTA cement, Dentsply Tulsa Dental, Tulsa, USA)를 이용하 여 근관 충전을 시행하였다. 이후 mineral trioxide aggregate 상방은 gutta-percha cone으로 충전하였고 별도의 포스트는 사용하지 않았다. 치은 연하로 연장된 파절선 때문에 복합 레진 충전을 위한 방습에 어려움이 있어 글 래스 아이오노머(Ketac Fil, ESPE, Seefeld, Germany)로 근관 와동을 충전하였다.

근관 치료가 완료된 후 교정적 정출을 시작하였으며,

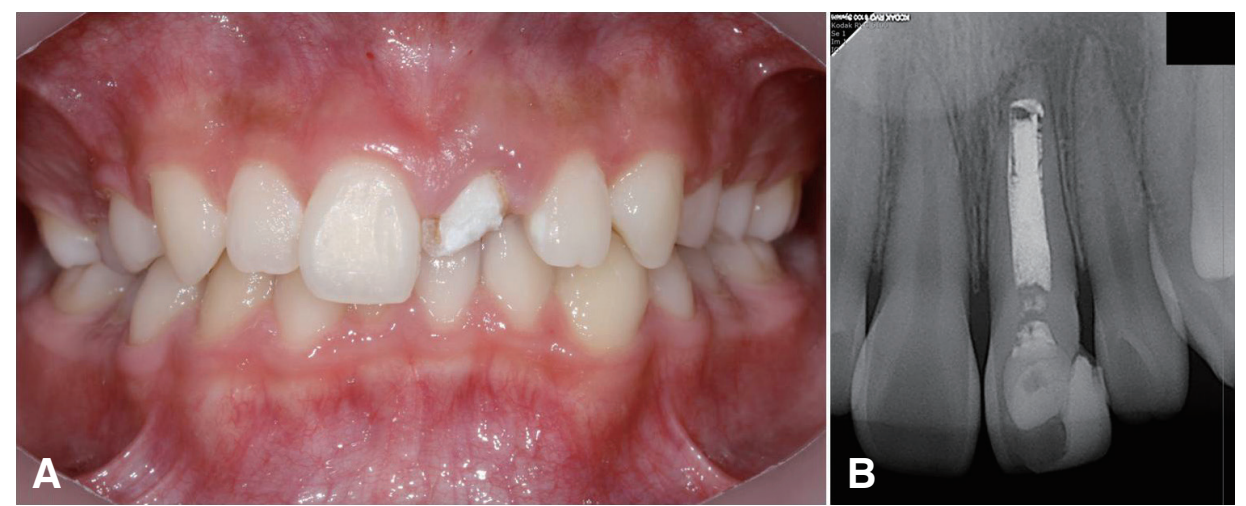

Fig. 1. Pretreatment clinical view and radiograph of case 1. Note fracture line of maxillary left central incisor extended below the buccal gingival after removal of fractured buccal crown fragment (A). Figure (B) represents the initial state which was not removed fractured buccal crown fragment. 
파절된 상악 좌측 중절치를 제외한 상악 우측 견치에서 상악 좌측 견치까지의 5 개 치아에서 $0.019 \times 0.025$-inch stainless steel 호선을 부착하여 고정원(anchor)을 보강 하였다. 정출을 위해 상악 좌측 중절치 순면에 lingual button (ORMCO, Glendora, USA)을 부착한 후 elastic thread를 사용하여 견인하였다. 이 때 gauge (DT-500G, TECLOCK Co. Ltd., Nagano, Japan)를 이용하여 25 $\mathrm{gm}$ 의 힘이 적용되는 것을 확인하였다. 교정적 정출술 동 안 치료의 진행 정도를 확인하고 elastic thread 교체를 위 해 환자를 2 주 마다 내원하도록 하였으며, 별도의 치은섬 유 절단술은 시행하지 않았다.

교정적 정출을 시작한지 10 주가 되는 시점에 치근단 방사선 사진 및 구강내 확인을 통해 수복에 필요한 정출 이 이루어졌음을 확인하였다. 유지를 위해 결찰용 철선
으로 순면에 부착된 lingual button과 stainless steel 호선 을 수동적으로 연결하여 6주간 기다리도록 하였다(Fig. 2). 6 주의 유지기간이 지나고 나서 생물학적 폭경의 재확 립 및 인접 치은 조직과의 조화를 위해 치은 절제술 및 치 조골 삭제를 동반한 치관 연장술을 시행하였다(Fig $3 \mathrm{~A}$, $3 \mathrm{~B})$. 치관 연장술 후 연조직 회복 및 교정적 정출술 후 재 발 방지를 위해 유지 장치를 부착한 상태로 4주간 더 기 다리도록 하였다. 총 10 주의 유지기간이 지나고 나서 모 든 교정 장치를 제거하고 근관 와동에 충전된 글래스 아 이오노머를 제거하고 복합 레진(LuxaCore, DMG, Hamburg, Germany)으로 충전한 후 임시치아를 제작하였다. 이후 치주 조직이 치유되는 동안 임시치아를 계속적으로 조절하였다. 치관 연장술 6 주째 치은 조직의 약간의 재조 정이 필요하여 치은 절제술을 이용한 치관 연장술을 한
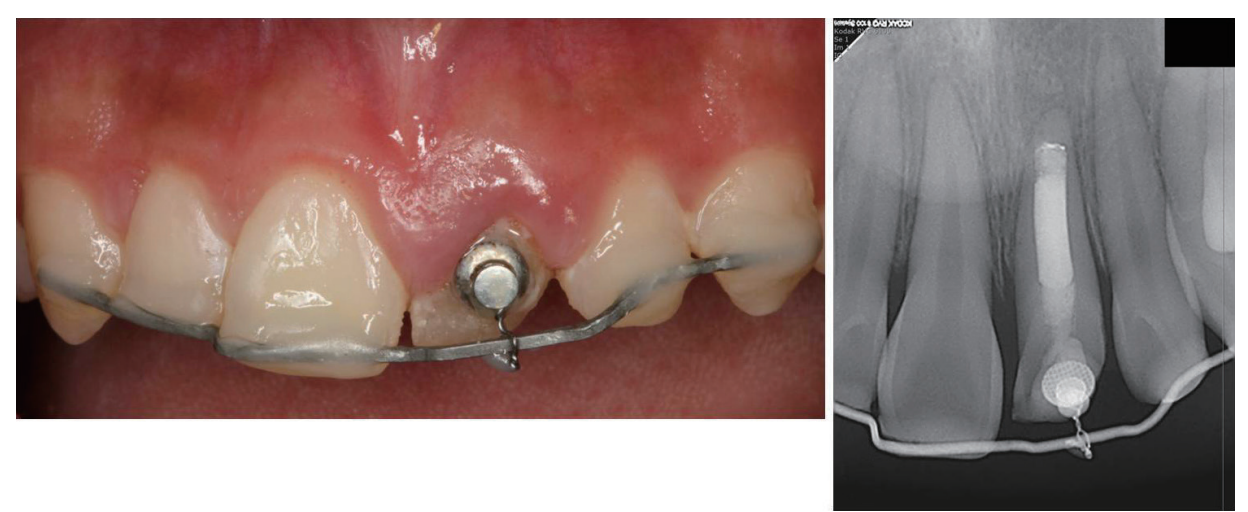

Fig. 2. After a 10 -week orthodontic extrusion and followed by a 6 -week retention phase. Note the coronal migration of the gingiva in the buccal aspect of extruded tooth.
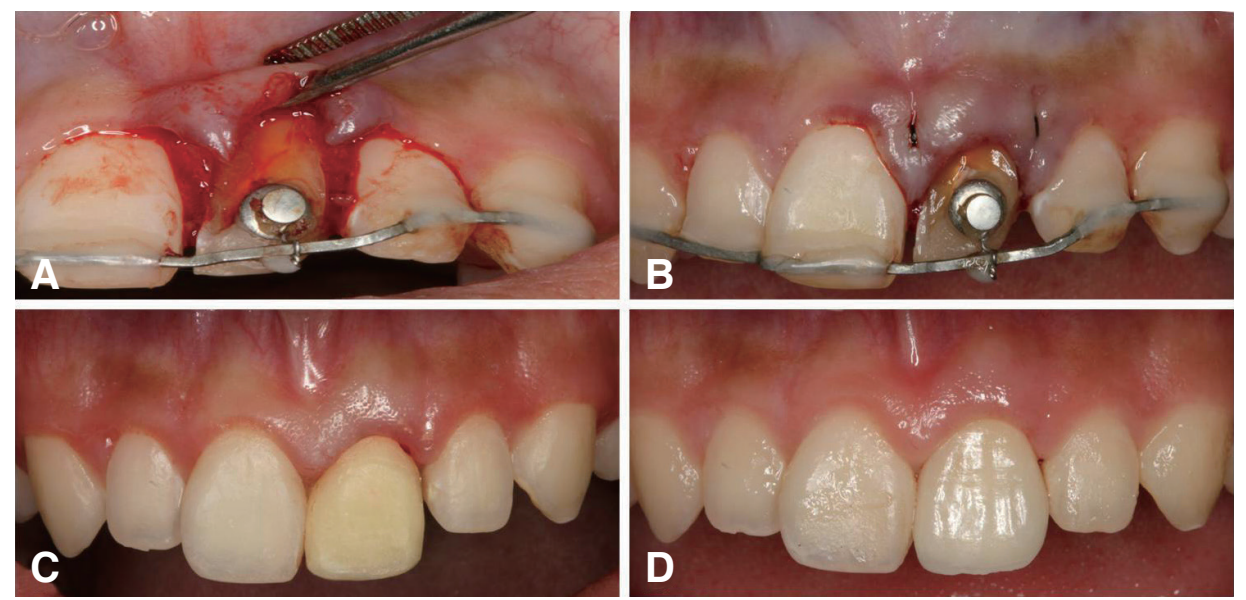

Fig. 3. During surgical clinical crown lengthening, the flap was reflected and osseous resection was performed to achieve adequate distance for biological width with exposure of fracture margin (A). The flap was sutured back to the position (B). Temporary crown was adjusted for marginal gingival adaptation (C). After final prosthetic crown placement (D). 
번 더 시행한 후 임시치아를 수정하였다(Fig. 3C). 2개월 후 원하는 치은 외형이 얻어졌음을 확인하고 최종 인상 채득 및 최종 보철물 장착을 완료하였다(Fig $3 \mathrm{D})$. 최종 보철물 장착과 동시에 재발 방지를 위해 상악 6전치 설면 에 고정식 유지 장치를 부착하였다.

\section{증례 2}

19세 남자 환자로 외상으로 상악 좌, 우측 중절치가 파 절되어 발치 및 임플란트 식립을 희망하여 본원에 내원하 였다. 상악 우측 중절치는 치관부에 한정된 파절로 근관 치료 후 광중합 복합 레진으로 수복하기로 하였다. 그러 나 상악 좌측 중절치는 치관부 치질이 거의 남아있지 않 은 상태였고 파절선이 치은 연하로 연장되어 있었으며 치 수가 이미 노출된 상태였다(Fig. 4). 환자의 나이가 19세 로 젊은 편에 속하고 파절선이 치근의 치경부 $1 / 3$ 이내에 위치하였고 비교적 치조골내 치근 부위 길이가 충분하다 고 판단하여 발치 하지 않고 수복할 것을 고려하였다. 이 경우 발치하지 않고 수복하여 사용할 경우 심미성의 문 제 때문에 치조골 삭제를 동반한 치관 연장술을 바로 시 행할 수 없었고 정출술이 먼저 필요한 상태로 판단되었 다. 환자가 장기간의 치료나 복잡한 교정장치 등을 원치 않아서 외과적 정출술을 시행한 후 수복하기로 하였다.

외과적 정출을 시행하기에 앞서 외상으로 치수가 노 출된 상태였기 때문에, 처음 내원한 당일에 발수 후 근관 내 수산화 칼슘 첨약을 시행하였고 Caviton (GC, Tokyo, Japan)으로 임시가봉을 하였다. 외과적 정출술을 시행하 기 전 근관 치료를 완료하려 했으나 러버댐을 이용한 격
리 및 방습이 불가능하였다. 이에 근관 치료를 더 이상 진 행하지 않고 외과적 정출술을 먼저 시행하기로 결정하였 다. 외과적 정출술 시행시 판막을 거상 후 elevator로 치 근의 탈구를 유도하며 치아 및 주위 치조골이 파절되지 않도록 주의를 기울였다. Forcep을 이용하여 발치 하였 으며 구강외에서 치근 표면 및 파절선의 경계를 직접 확 인 후 치아의 설측이 협측으로 위치하도록 180 도 회전시 켜 치조골내로 재위치 시켰다. 이 때 발치 후 재위치 까지 는 약 30 초 정도 소요되었다. 이후 생물학적 폭경을 확보 하면서 파절선을 치조골 상방으로 노출시키기 위해 원하 는 위치에 광중합 복합 레진을 이용하여 인접치에 고정 시켰다(Fig. $5 \mathrm{~A}$ ). 술후 1주가 지나서 봉합사를 제거하고 다시 근관 치료를 진행하였다(Fig. $5 \mathrm{~B}$ ). 술후 2 주째 인접 치에 고정하였던 레진을 제거하였고 이후 수차례의 근관 세척을 시행하였다. 완전히 성숙한 영구치였으므로 통상 적으로 근관 충전시 사용되는 gutta-percha cone으로 근 관 충전을 시행하였고 인접 치은 조직과의 조화로운 형 태를 가진 수복물 제작을 위해 치은 절제술을 동반한 치 관 연장술을 시행하였다. 연조직 회복이 된 4주 후 포스 트 삽입 및 코어 축조 후 임시 치관 수복을 시행하였다 (Fig. 5C, 5D). 치관 연장술 후 2개월 간의 주변 치주 조직 의 치유 기간을 거쳐 최종 인상 채득 및 보철물 수복을 시 행하였고(Fig. 6A), 임시 치관 장착시 그리고 최종 보철물 장착 직후의 치간 유두 높이에 비해 최종 보철물 장착 후 2년 경과시 치간 유두의 높이가 더 높아진 것으로 관찰되 었다(Fig. 6B). 방사선 사진에서 최종 보철물 장착시 그리 고 추적 관찰 기간 동안 치근단 부위에서 방사선 투과상 이 점차 소실됨을 확인하였다(Fig. 7).

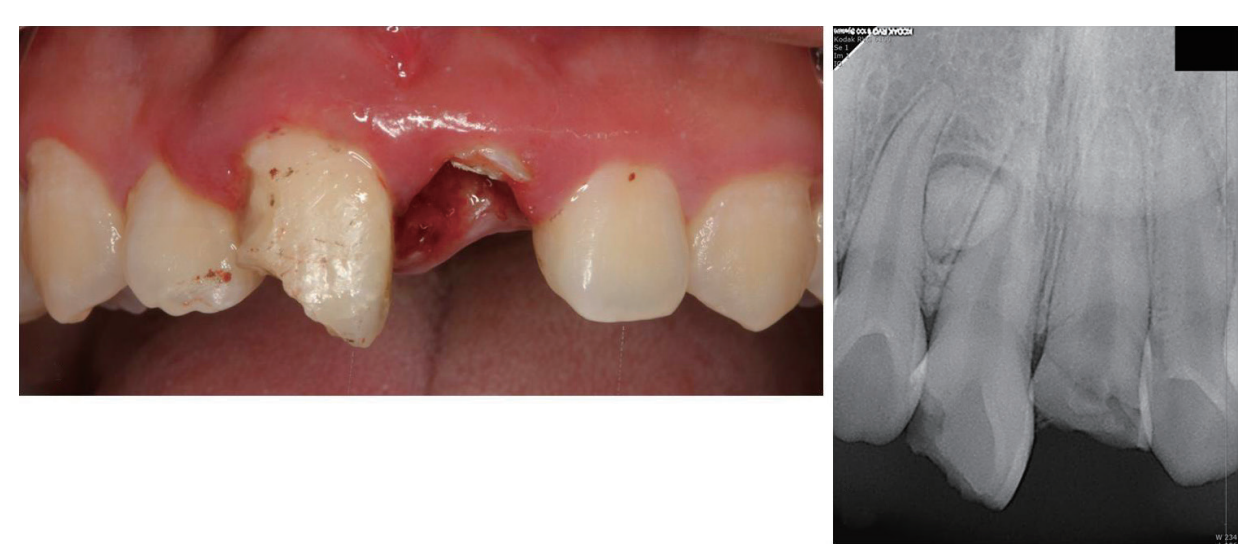

Fig. 4. Pretreatment clinical view and radiograph of case 2. Note fracture lines of maxillary right and left central incisor. Right central incisor was fractured above the gingival line but left central incisor showed the biologic width violation by subgingival crown fracture with complete loss of the crown. 

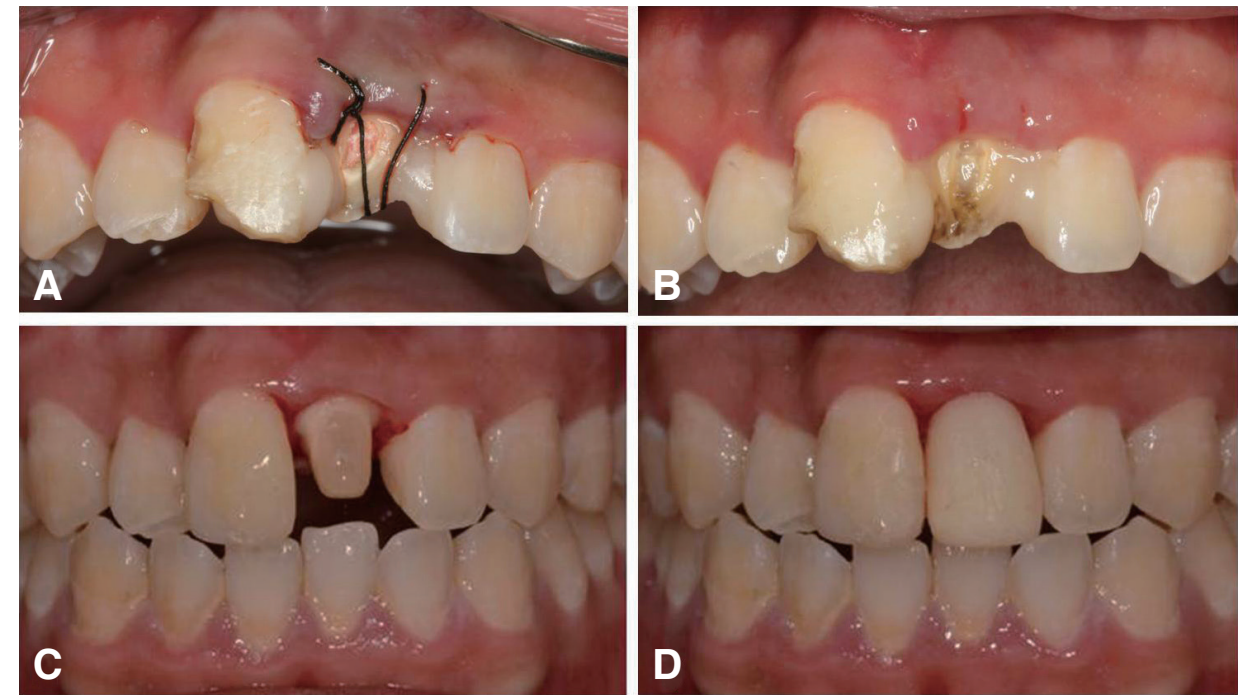

Fig. 5. Buccal view of coronally positioned root splinted with composite resin to maintain tooth stability and sutured (A). One-week after surgical extrusion. Wound healing was uneventful and suture was removed (B). After complement of endodontic treatment and gingivectomy, reconstruction of crown with core and post was done (C). Temporary crown was adjusted for marginal gingival adaptation (D).
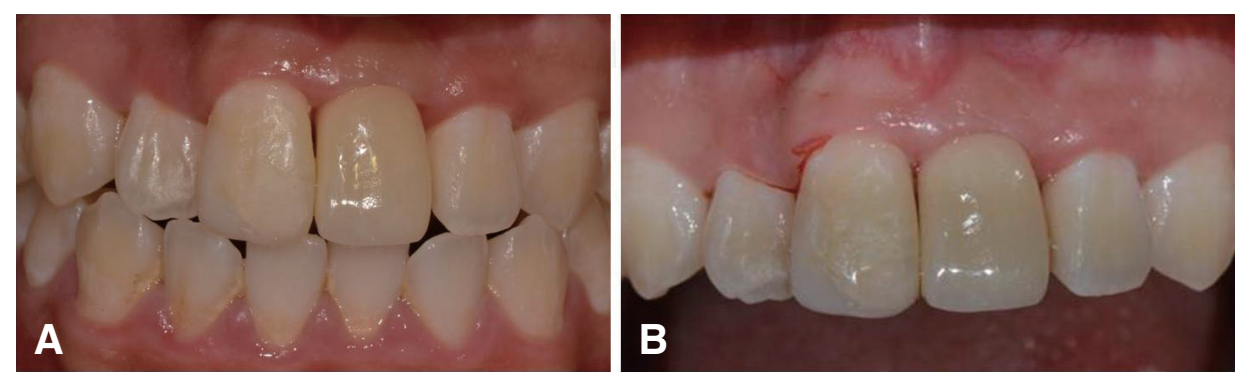

Fig. 6. Clinical view after final prosthetic crown placement (A). Two-year follow-up clinical view showed harmonious soft tissue contour (B).
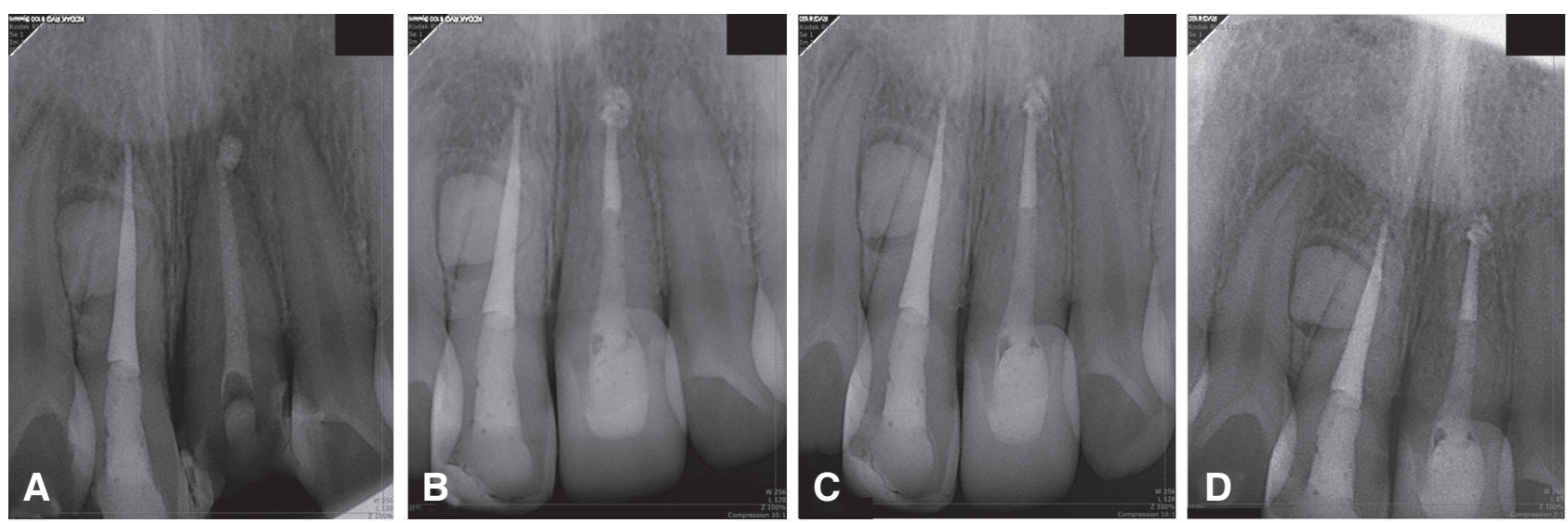

Fig. 7. Radiograph taken right after surgical extrusion (A), at crown delivery (B), at 1-year follow-up (C) and at 2-year follow-up (D). Note the resolution of periapical radiolucency and there was no signs of root resorption or ankylosis. 


\section{고찰}

교정적 정출술은 여러 가지 상황에서 적절한 치료법으 로 적용될 수 있다. 첫번째로는 느린 수직적 정출력을 적 용하여 고립된 골연하 병소의 치료에 이용될 수 있다. 정 출력이 가해지는 동안 치은 섬유 조직이 신장됨으로써, 치조정에서 골침착을 자극하여 골연하 병소의 제거가 이 루어진다. ${ }^{4}$ 두번째로는 특히 치근의 치경부 $1 / 3$ 지점에서 발생한 파절, 깊은 우식, 천공, 치근 외흡수 등과 같은 다 양한 상황에서 치료하는데 사용될 수 있다. 치료 목표는 치근의 이환 부위를 치조정 상부로 끌어올려 이환 부위 를 노출 시키고 생물학적 폭경을 침범하지 않는 수복을 가능하게 하는데 있다. ${ }^{4}$ 세번째로는 특히 전치부에서 치 은 퇴축 등의 연조직 부조화를 치료하고자 할 때 적용된 다. 치료의 목표는 교정적 정출술로 경조직, 연조직 둘 다 의 형태 변화를 유도하여 부적절한 치은 변연을 수정, 개 선시키는 것이다. ${ }^{4}$ 네번째로는 치주 질환에 이환된 치아 에서 임플란트 수복전 치조골 형태를 유지 또는 재확립 하기 위해 사용될 수 있다. 이 경우 교정적 정출술을 통해 임플란트 식립전 치주 질환에 의해 손상된 경조직, 연조 직을 먼저 회복시켜 치주 수술로는 획득하기 어려운 심 미적인 치료 결과를 얻을 수 있다. ${ }^{6}$ 본 증례에서는 두번째 경우인 치근의 치경부 $1 / 3$ 지점에서 파절된 치아를 수복 하기 위해 교정적 정출술이 시행되었고 그 결과 파절선이 치은 연상으로 이동되어 수복이 가능하였다.

교정적 정출시 주위 골과 치은 조직의 약간의 움직임 이 항상 일어나는데, 정출이 가벼운 힘과 느린 속도로 일 어나면 이런 변화는 덜 현저하다. ${ }^{7}$ 완속 정출을 위한 최 대 힘은 $30 \mathrm{gm}$ 을 넘지 않아야 하는 반면, 급속 정출을 위 해서는 $50 \mathrm{gm}$ 이상의 힘이 가해지기도 한다. 완속 정출 은 이동 속도가 1 주에 대략 $1 \mathrm{~mm}$ 를 넘지 않도록 주의하 는데, 이 때 가해지는 힘은 환자의 생리적 반응과 치근 표 면 형태와 같은 다른 요소들에 따라 조금씩 달라질 수 있 다. ${ }^{4}$ 본 증례에서는 완속 정출을 시행하기 위해 내원시 마 다 $25 \mathrm{gm}$ 의 힘이 적용되는 것을 확인하였다.

교정적 정출 이후 치근이 원래의 자리로 돌아가려고 하 는 현상을 방지 하기 위해 최종 수복전 치근을 새로운 위 치에 일정기간 유지시키는 것이 중요하다. 유지기간에 대 해서는 다양한 의견들이 존재하며, 통상적으로 많은 학 자들이 6주 이상을 추천하였다. ${ }^{4,6}$ 본 증례에서는 정출 이 후 총 10 주간의 유지기간을 거쳤으며 처음 6 주간의 유지 기간이 지나고 나서 인접 치주 조직과의 사이에 생긴 부
조화를 바로잡기 위해 치관 연장술을 시행하였다. 이후 연조직 회복 및 교정적 정출술 후 재발 방지를 위해 유지 장치를 그대로 부착한 상태로 4 주를 더 기다리도록 하고 최종 수복을 진행하였다. 교정적 정출술 완료 후 재발을 방지하기 위해 교정적 정출술 중이나 완료 후 치은섬유 절단술을 추천하기도 한다. ${ }^{8,9}$ 그러나 일부 학자들은 치은 섬유 절단술은 예지성이 떨어지며 치은과 골개조는 유지 기간 이후에도 일어난다고 주장하였다. ${ }^{10}$ 본 증례에서도 별도의 치은섬유 절단술은 교정적 정출술 중이나 완료 후 시행하지 않았으나, 재발을 방지 하기 위해 최종 보철 물 장착시 상악 전치부 설측에 영구적인 고정식 유지 장 치를 부착하였다.

교정적 정출술은 예측 가능한 결과를 가져다 준다는 점에서 파절된 치아를 수복하기 위한 효과적인 치료이나 유착이 있거나 과백악질증, 수직적으로 치근이 파절된 경 우, 두 치근이 서로 근접해 있거나, 치근 길이가 짧은 편 일 때, 적절한 보철 수복 공간이 확보가 되지 않거나 정출 로 인해 이개부가 노출될 위험이 있는 경우에는 시행을 신중히 고려해야 한다. ${ }^{11}$ 또한 수개월의 정출 기간이 요구 되고 구강내 교정 장치를 써야 하므로 환자는 일시적이 나 심미적 문제점을 가져야 하며 이것은 구강 위생을 나 쁘게 할 수 있다. 추가적으로 단근치에서 정출이 계속되 면서 치근의 근원심 직경이 감소하게 되어 인접 치아 사 이의 공간 확장을 야기할 수 있는 문제점이 있다. ${ }^{4}$

이러한 문제를 극복하기 위해 고려해 볼 수 있는 외과 적 정출술은 파절된 치아를 발치하여 새로운 위치에 고 정시키는 방법으로 한번의 술식만으로 정출이 완료되므 로 교정적 정출술보다 방법이 훨씬 간단하고 시간이 적 게 걸리는 장점이 있다. ${ }^{5}$ 그러나 이 술식은 치근 형성이 완 전히 일어난 치아와 외과적 정출술 이후 수복할 때 치관치근 비율이 최소 $1: 1$ 은 유지될 수 있는 치아에 시행하는 것이 좋다. ${ }^{12}$ 또한 발치시 추가적인 파절로 치아를 아예 상실할 경우가 생길 수 있으므로 술식 중 매우 주의를 기 울여야 한다.

본 연구에서 두 환자 모두 치아를 발치 하지 않고 수복 하는 것이 목표였으나 인접치와의 심미적 조화 문제 때 문에 초진 상태에서 치관 연장술만 단독으로 시행하는 것은 결코 고려할 수 없었다. 따라서 치관 연장술을 시 행하기 전에 정출술이 먼저 필요하다고 판단하였다. 첫 번째 증례의 환자는 시술로 인한 발치의 가능성이 최대 한 낮은 보존적인 치료를 희망하였으므로 외과적 정출술 은 고려하지 않고 교정적 정출술을 시행하였다. 반면, 두 
번째 증례의 환자는 교정 장치를 부착하는 장기간의 치 료를 원치 않아서 비교적 단기간의 치료기간이 소요되는 외과적 정출술을 먼저 고려하였다.

치관부 손상이 심한 치아에서 보철물에 적절한 유지력 을 주기 위한 방법으로 포스트와 코어의 이용을 고려해 볼 수 있다. 근관 치료를 받은 치아가 교합력을 받을 때, 응력이 치경부에 가장 집중되므로, 근관 치료를 받은 치 아에서 포스트를 위치시키는 것은 이 부위에서 응력을 줄여준다는 보고가 있다. ${ }^{13}$ 그러나 포스트를 사용함으로 발생되는 치근 파절에 대한 문제점들이 논란이 되어 오 고 있다. 수복물의 파절 저항성은 포스트 존재 자체보다 잔존 치질 양에 더 많은 영향을 받기 때문에 상아질의 양 이 증가 할수록 파절 저항성이 커진다는 연구 결과가 발 표되었다. ${ }^{14}$ 따라서 치질 손상이 많은 치아에서 포스트와 코어를 이용할 경우 가장 우선적으로 고려해야 할 것은 잔존 치질 양이며, 포스트 직경이 백악-법랑 경계에서 치 근 직경의 $1 / 3$ 을 넘지 않아야 한다고 알려져 있다. ${ }^{15}$ 적절 하지 않은 포스트의 두께 증가는 잔존 치질의 감소로 이 어져 파절 저항성을 감소시킬 수 있기 때문이다.

본 연구에서 두 증례의 환자 모두 치관부가 협측에서 절반 이상 소실된 상태로 포스트가 필요하다고 볼 수도 있다. 두번째 증례의 환자는 근관 내 하방 부위를 guttapercha cone으로 충전하고 상방에 포스트를 위한 와동 을 형성한 후 포스트를 삽입하고 코어를 축조 후 지대치 형성을 위한 삭제를 시행하였다. 그러나 첫번째 증례의 환자의 경우 근관 자체가 매우 넓은 상태로 포스트를 삽 입시 그 직경이 치근 폭의 $1 / 3$ 을 넘어서게 되고 포스트 주위로 잔존 치질이 많이 남지 않을 것으로 판단되었다. 따라서 포스트를 사용하면 오히려 치아 파절 위험이 더 높아질 수도 있을 것으로 예상되었다. 또한 교정적 정출 술이 완료된 후 구강내 잔존 치질을 평가시 포스트 없이 코어만으로 치관부 수복물의 유지력을 얻는 것이 가능할 것으로 추정되어 포스트를 사용하지 않았다.

치근 흡수나 유착이 외과적 정출술 이후 간혹 발생할 수 있는데, 이는 치근을 탈구 시키는 동안 외과적 외상으 로 치조정 근처에서의 변연골 흡수와 치근단 부위에서 치근 흡수가 유도될 때 일어날 수 있다. ${ }^{16}$ 또한 발치 직후 구강외 환경에서 치주인대 세포의 탈수는 치근 흡수와 유착을 야기할 수 있다. 이전의 연구들에 의해 치근 표면 주위의 치주인대 세포들의 생존능력이 치조골 밖에 머무 르는 시간(extra-alveolar period)에 따라 감소할 수 있음 이 밝혀졌다. ${ }^{16}$ 본 증례에서도 술식 중 치조골을 최대한
손상시키지 않으면서 조심스럽게 발치를 시행하고 발치 후 치주인대의 생명력을 최대한 보존하기 위해 치아가 구강외에서 머무르는 시간을 최소화하도록 주의를 기울 였다. 또한 외과적 정출술 시행 중 구강외에서 역충전 등 을 고려할 수도 있으나, 본 증례의 경우 구강외 시간이 길 어져 자칫 치근 흡수나 유착이 발생할 것을 우려하여 발 치 후 치근 상태만 확인 후 바로 재위치 시켰다.

외과적 정출술 후 초기 안정은 중요한데 이는 치조골 내 혈병 형성과 연관되어 있기 때문이다. 대개의 경우 치 주인대의 빠른 치유 과정으로 몇 주 이내 즉각적인 동요 도 감소가 일어난다. ${ }^{17}$ 외과적 정출술에서 새로운 위치에 치근을 고정시키기 위해 여러 가지 방법이 고려될 수 있 다. 치간부 봉합만으로 고정하기도 하며, 경우에 따라 인 접치에 고정시키는 splint가 흔히 사용되기도 한다. 봉합 만으로 고정하는 것은 약간의 동요도를 허용함으로써 치 유 기간 동안 기능적 자극이 가해지도록 하는 방법으로 이는 유착과 흡수를 방지함으로써 더 좋은 예후를 가져 다 준다는 보고도 있다. ${ }^{5}$ 다만 교합성 외상으로 인한 과 도한 자극은 유착이나 치근 흡수를 방지하지 않고 오히 려 골생성 및 치유를 방해할 수 있어 주의를 기울여야 한 다. 본 증례에서는 치관-치근 파절로 인해 치관부 치질이 거의 남지 않아서 치간부 봉합만으로는 원하는 위치로 치관측으로 치아를 발치후 재위치 시키기 어려워 인접치 에 광중합 복합 레진으로 고정시켰다.

외과적 정출술을 시행할 경우 근관 치료 시작 시점에 대해서는 학자들마다 의견이 분분하다. Elkhadem 등 $^{18}$ 의 체계적 문헌 고찰에 따르면 여러 증례 보고들에서 외과 적 정출술 이전에 근관 충전까지 완료한 경우는 약 $15 \%$ 정도이며, 증례의 $75 \%$ 에서 외과적 정출술 이후 근관 충 전에 이르기까지 $1-12$ 개월간 근관내 수산화 칼슘 첨약 후 근관 충전을 완료하였다고 한다. 일부 연구에서는 외 과적 정출술 전에 시행하는 근관 치료는 대개의 경우 러 버댐을 이용하기 어려우므로 타액과 혈액으로부터의 미 생물 감염이 발생하기 때문에 이점이 없다고도 발표하였 다. ${ }^{19}$ 따라서 외과적 정출이 시작되기 전에 격리 및 방습 이 제대로 이루어진 근관 치료가 완료될 수 있다면 근관 충전까지 마무리하는 것이 일반적이다. 그러나 격리 및 방습이 어렵다면 외과적 정출술을 이용하여 근관치료 및 수복을 위한 접근성을 개선 시킨 이후에 근관치료를 완 료하는 것이 추천될 것이다. 본 연구의 두번째 증례의 환 자에서 처음 내원 당시 치은 출혈이 심하였고 치은 연하 로 연장된 파절선으로 인해 격리 및 방습 자체가 어려워 
외과적 정출술 전에 근관 충전까지 마무리 하기가 거의 불가능하였다. 이에 노출된 치수를 처치하기 위한 발수 및 근관내 첨약, 임시 가봉만 시행하였고, 외과적 정출술 이후 파절선이 치은 연상으로 위치되고 난 후 나머지 근 관 치료를 진행하였다.

치간유두 높이를 결정짓는 데는 다양한 요소가 관여하 며 여기에는 치조골정 높이, 접촉점에서 치조정까지의 거 리, 얇거나 두꺼운 연조직 형태, 협측 골판 두께, 치아의 외형과 관련된 접촉 지역(contact area) 등이 존재한다. ${ }^{20}$ 본 연구의 두번째 증례의 환자에서 상악 중절치 형태가 네모난 형태(square shape)로 두 중절치 사이에서 좁은 접촉점이 형성되기 보다는 넓은 접촉면이 형성되는 것이 관찰되었다. 또한 치주조직이 두껍고 편평한 형태(thick, flap biotype)를 보이고 있어, 이런 경우 삼각형 형태(triangular shape)의 치아나 치주조직이 얇고 부채꼴 형태 (thin, scalloped biotype)를 지닌 환자보다 치간 유두가 보철 수복 후 채워지기 쉬운 조건으로 가지고 있다고 볼 수 있다. 실제로 본 연구의 두번째 증례 환자에서 치은 절 제술 후 임시 치관 장착시 그리고 최종 보철물 장착 직후 의 치간 유두 높이보다 최종 보철물 장착 2 년째 치간 유 두 높이가 더 높은 것이 관찰되었다.

\section{결론}

외상으로 상악 중절치에서 치관-치근 파절이 발생한 경우에 파절 부위를 노출시키고 수복을 위한 생물학적 폭경을 확보하기 위해 교정적 정출술 또는 외과적 정출 술을 통한 다각적 방법을 병용함으로써 심미성을 훼손시 키지 않으면서 성공적으로 수복할 수 있었다.

\section{Acknowledgements}

This work was supported by clinical research grant from Pusan National University Hospital in 2020.

\section{ORCID}

Eun-Young Kwon https://orcid.org/0000-0001-9555-0360

So-Yeun Kim https://orcid.org/0000-0001-6714-8315

Kyoung-Hwa Jung https://orcid.org/0000-0002-8305-0016

Youn-Kyung Choi https://orcid.org/0000-0003-1491-2986

Hyun-Joo Kim https://orcid.org/0000-0001-7553-6289
Ji-Young Joo https://orcid.org/0000-0002-4050-5797

\section{References}

1. Sorensen JA, Engelman MJ. Ferrule design and fracture resistance of endodontically treated teeth. J Prosthet Dent 1990;63:529-36.

2. Jotkowitz A, Samet N. Rethinking ferrule - a new approach to an old dilemma. Br Dent J 2010;209: 25-33.

3. Ingber JS, Rose LF, Coslet JG. The "biologic width" - a concept in periodontics and restorative dentistry. Alpha Omegan 1977;70:62-5.

4. Bach N, Baylard JF, Voyer R. Orthodontic extrusion: Periodontal considerations and applications. J Can Dent Assoc 2004;70:775-80.

5. Çalişkan MK, Türkün M, Gomel M. Surgical extrusion of crown-root-fractured teeth: a clinical review. Int Endod J 1999;32:146-51.

6. Buskin R, Castellon P, Hochstedler JL. Orthodontic extrusion and orthodontic extraction in preprosthetic treatment using implant therapy. Pract Periodontics Aesthet Dent 2000;12:213-9.

7. Arhun N, Arman A, Ungor M, Erkut S. A conservative multidisciplinary approach for improved aesthetic results with traumatised anterior teeth. $\mathrm{Br}$ Dent J 2006;201:509-12.

8. Palomo F, Kopczyk RA. Rationale and methods for crown lengthening. J Am Dent Assoc 1978;96:25760.

9. Malmgren O, Malmgren B, Frykholm A. Rapid orthodontic extrusion of crown root and cervical root fractured teeth. Endod Dent Traumatol 1991; 7:49-54.

10. Lovdahl PE. Periodontal management and root extrusion of traumatized teeth. Dent Clin North Am 1995;39:169-79.

11. Smidt A, Lachish-Tandlich M, Venezia E. Orthodontic extrusion of an extensively broken down anterior tooth: a clinical report. Quintessence Int 2005;36:89-95.

12. Kahnberg KE. Surgical extrusion of root-fractured teeth - a follow-up study of two surgical methods. Endod Dent Traumatol 1988;4:85-9.

13. Ottl P, Hahn L, Lauer HC, Fay M. Fracture char- 
acteristics of carbon fibre, ceramic and non-palladium endodontic post systems at monotonously increasing loads. J Oral Rehabil 2002;29:175-83.

14. Assif D, Gorfil C. Biomechanical considerations in restoring endodontically treated teeth. J Prosthet Dent 1994;71:565-7.

15. Stern N, Hirshfeld Z. Principles of preparing endodontically treated teeth for dowel and core restorations. J Prosthet Dent 1973;30:162-5.

16. Andreasen JO, Kristerson L. The effect of limited drying or removal of the periodontal ligament. Periodontal healing after replantation of mature permanent incisors in monkeys. Acta Odontol Scand 1981;39:1-13.

17. Kim SH, Tramontina V, Passanezi E. A new approach using the surgical extrusion procedure as an alternative for the reestablishment of biologic width. Int J Periodontics Restorative Dent 2004;24:39-45.

18. Elkhadem A, Mickan S, Richards D. Adverse events of surgical extrusion in treatment for crown-root and cervical root fractures: a systematic review of case series/reports. Dent Traumatol 2014;30:1-14.

19. Das B, Muthu MS. Surgical extrusion as a treatment option for crown-root fracture in permanent anterior teeth: a systematic review. Dent Traumatol 2013;29:423-31.

20. Zetu L, Wang HL. Management of inter-dental/inter-implant papilla. J Clin Periodontol 2005;32:8319. 


\section{치관-치근 파절이 발생한 상악 중절치를 수복하기 위한 다각적 접근법: 교정적 정출술과 외과적 정출술}

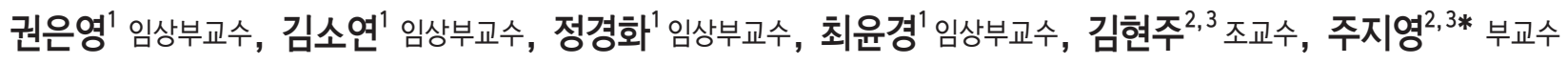
${ }^{1}$ 부산대학교병원 치과진료센터

${ }^{2}$ 부산대학교 치의학전문대학원 치주과학교실

${ }^{3}$ 부산대학교 치과병원 치주과

변연골 하방으로까지 파절선이 연장된 치아를 수복하기 위해 파절선의 노출 및 생물학적 폭경의 재확립을 위한 삭제형 골수술을 동반한 외과적 치관 연장술을 고려해 볼 수 있다. 그러나 이 술식은 특히 전치부에서 심미성을 훼손시킬 수 있 다. 따라서 지지골과 치은을 희생시키지 않으면서 파절선을 치조와 하방에서 상방으로 위치 시킬 수 있는 교정적 정출술 이 권장된다. 이 술식은 생물학적 폭경의 재확립과 더불어 수복물을 건전한 치아 구조에 위치할 수 있도록 해 준다. 또 다 른 대안으로, 교정적 정출술 보다 방법이 간단하며 시간이 적게 소요되고 한번의 술식만으로 정출이 완료되는 외과적 정 출술도 고려해 볼 수 있다. 외과적 정출술을 이용할 경우 구강내 교정 장치를 위치시키고 조정하기 위해 환자가 치과에 여러번 방문할 필요가 없다. 본 연구에서는 상악 중절치에서 치관-치근 파절이 발생한 경우 교정적 정출술 또는 외과적 정출술을 통한 다각적 방법을 병용함으로써 성공적으로 수복한 증례를 보고하고자 한다.

(구강회복응용과학지 2020;36 (4):262-71)

주요어: 교정적 정출술; 외과적 정출술; 치관 연장술; 치아 파절

*교신저자: 주지영

(50612)경남 양산시 물금읍 금오로 20 부산대학교 치의학전문대학원 치주과학교실

Tel: 055-360-5103 | Fax: 055-360-5194 || E-mail: joojy@pusan.ac. kr

접수일: 2020년 8월 14일 | 수정일: 2020년 9월 7일 | 채택일: 2020년 9월 9일 